\title{
The behavior of Troponin I and CKMB mass in children who underwent surgical correction of congenital heart malformations
}

Comportamento da troponina I e CK-MB massa em crianças submetidas a correção cirúrgica das cardiopatias congênitas

Pedro Rafael SALERNO, Fabio Biscegli JATENE, Patrícia Elias FIGUEIREDO, Ieda Jatene BOSISIO, Marcelo Biscegli JATENE, Magaly Arraes dos SANTOS, Luís Carlos Bento de SOUZA, Adib Domingos JATENE

RBCCV 44205-643

\section{Abstract}

Objective: To analyze the behavior of troponin (TROP I) and CKMB mass (CKMBm) in regards to the addition of magnesium in cardioplegic solutions; and also the influence of per-operative factors.

Method: A total of 28 children with ages ranging from 3 to 108 months were studied. The mean weight was $11.8 \mathrm{~kg}$. Eighteen were male. The patients were divided into two groups. Sixteen children in group I (GI) and 12 in group II (GII). The patients in GI received cold blood cardioplegic solution with magnesium $(12 \mathrm{mEq} / \mathrm{L})$ and potassium chloride $(20 \mathrm{mEq} / \mathrm{L})$ at $20 \mathrm{~mL} / \mathrm{kg}$. The patients in GII received the same solution without magnesium. Six blood samples were collected for serum analysis of the concentration of TROP I and CKMBm. The blood samples were collected before clamping the aorta and at 1, 6, 24, 48 and 72 hours after aorta clamping termination.

Results: There were no statistical differences in the TROP $I$ and CKMBm levels between the two groups. Among the per-operative factors cyanosis influenced the TROP I and CKMBm levels. Additionally, the aorta clamping time influenced the TROP I levels.

Conclusions: The addition of magnesium in the cardioplegic solution was not associated with different levels of TROP I and CKMBm. Cyanosis and aorta clamping time interfered with peak TROP I levels.

Descriptors: Troponin I, blood. Creatine kinase, blood. Heart defects, congenital, surgery. Magnesium sulfate, therapeutic use. Cardioplegic solutions, chemistry.

Work performed in the Hospital do Coração da Associação Sanatório Sírio and the Instituto do Coração do Hospital das Clínicas, Medical School, University of São Paulo, São Paulo, SP, Brazil Correspondence address: Pedro Rafael Salerno. Av. Boa Viagem, 4138 apto 201. Boa Viagem. Recife, PE. CEP 51020-001. Phone/Fax: (081) 3421-4344 ex.1221.

E-mail: pedro-salerno@uol.com.br 


\section{Resumo}

Objetivo: Analisar o comportamento da troponina I (TROP I) e CKMB massa (CKMBm) conforme a adição ou não de magnésio (Mg) na cardioplegia e a influência dos fatores operatórios.

Método: Foram estudadas 28 crianças com a idade de 3 a 108 meses, peso médio de $11,8 \mathrm{~kg}$, sendo 18 do sexo masculino, divididas em dois grupos, 16 no grupo I (GI) e 12 no grupo II (GII). O GI recebeu solução cardioplégica sangüínea fria com $M g 12 \mathrm{mEq} / \mathrm{L}$ e cloreto de potássio $20 \mathrm{mEq} / \mathrm{L}$ na dose de $20 \mathrm{~mL} /$ kg. O GII recebeu a mesma solução sem o $(\mathrm{Mg})$. Foram coletadas seis amostras de sangue para a dosagem sérica de TROP I e CKMBm: pré-pinçamento da aorta e com 1, 6, 24, 48 e 72 horas após o término do pinçamento da aorta.

\section{INTRODUCTION}

The idea that the heart of children with congenital heart disease that needs to be corrected, would react to ischemia differently to adults stimulated several clinical and experimental studies to evaluate the differences in children's hearts and to find methods, which could minimize myocardial injury [1].

This difference in behavior of the myocardium of the child in relation to the adult, in response to cardioplegic ischemia, has been attributed to varying factors such as the myocardial structure, function and metabolism [2-8].

In a comparative study of different techniques of cardioplegia employed in the hearts of neonatal pigs, the solution of blood offered a better myocardial protection, when compared to crystalloid cardioplegia both with and without calcium [9].

Myocardial injury after ischemia and reperfusion leads to alterations in the levels of calcium ions [10]. As well as the calcium ions, magnesium would also be involved in ischemic myocardial injury [11].

Because of the subjectivity of the clinical parameters and of the invasiveness of biopsies, which are unable to reflect the aspect of the entire myocardium, the appearance of markers specific for myocardial injury such as the troponins and $\mathrm{CK}-\mathrm{MB}$ mass $(\mathrm{CKMBm})$ have enabled better evaluation of the myocardial damage $[12,13]$.

The aim of this study is to analyze whether the addition of magnesium in the cardioplegic solution will affect the serous levels of troponin I and CKMB mass in children submitted to congenital heart disease corrective surgery. A secondary aim was to verify if operative factors might interfere in the levels of troponin I and CKMB mass.

\section{METHOD}

In the period from January 2001 to February 2002, 259
Resultados: Os resultados demonstraram que não houve diferença estatisticamente significante nos níveis TROP I e CKMBm, entre GI e GII. Dentre os fatores operatórios, a cianose influenciou nos níveis de TROP I e CKMBm, enquanto que o tempo de pinçamento da aorta (TPA) influenciou nos níveis de TROP I.

Conclusões: A adição de Mg na solução cardioplégica não esteve associada com níveis diferentes de TROP I e CKMBm. A cianose e o TPA interferiram no pico de TROP I.

Descritores: Troponina I, sangue. Creatina quinase, sangue. Cardiopatias congênitas, cirurgia. Sulfato de magnésio, uso terapêutico. Soluções cardioplégicas, química.

children suffering from cyanotic and acyanotic congenital heart diseases were submitted to corrective surgery in the Hospital do Coração of the Association of Sanatório Sírio in São Paulo. Of these, 28 children fulfilled the criteria established for inclusion in this study.

All the parents received a letter giving information about this work and signed a written consent form. The Research Ethics Committee of the institution approved the study.

The study was a random case controlled trial composed of two groups. Group I, with 16 children, received myocardial protection using sanguineous cardioplegia with magnesium and Group II, comprising of 12 children, sanguineous cardioplegia without magnesium.

In both groups there were children with acyanotic and cyanotic congenital heart disease, where Fallot's tetralogy (28.5\%) and total atrioventricular septal valve defect (21.4\%) being the most common complaints.

Eighteen of the children were male. The ages ranged from 3 to 108 months, with a mean of 32.1 months and a standard deviation of 36.4 months. The weights varied from 3.5 to $35.5 \mathrm{~kg}$ with an average of $11.8 \mathrm{~kg}$ and standard deviation of $8.4 \mathrm{~kg}$

Children with ages less than 3 months or greater than 10 years, with hemodynamic instability, severe myocardial failure in the pre-operative period and undergoing emergency surgeries were not included in the study.

Cardiopulmonary bypass (CPB), systemic hypothermia at $26^{\circ} \mathrm{C}$, aortic clamping and sanguineous cardioplegia were employed in all the operations.

The dose of cardioplegia was $20 \mathrm{~mL} / \mathrm{kg}$ body weight and was repeated every 30 minutes with an infusion pressure of 60 to $80 \mathrm{mmHg}$. The composition of the cardioplegia was blood originating from the oxygenator perfusate, with the addition of an initial dose of $20 \mathrm{mEq} / \mathrm{L}$ potassium chlorate and subsequent doses of $15 \mathrm{mEq} / \mathrm{L}$. In Group I $12 \mathrm{mEq} / \mathrm{L}$ of magnesium sulfate was added in the initial dose and 

heart malformations

subsequent doses. The $\mathrm{pH}$, osmolarity and the concentrations of oxygen, carbon dioxide and sodium bicarbonate were the same as the oxygenator perfusate.

The cardioplegic system employed consisted of a mini heat exchanger connected to a shunt of the CPB circuit by a $1 / 4$ inch tube (Figure 1).

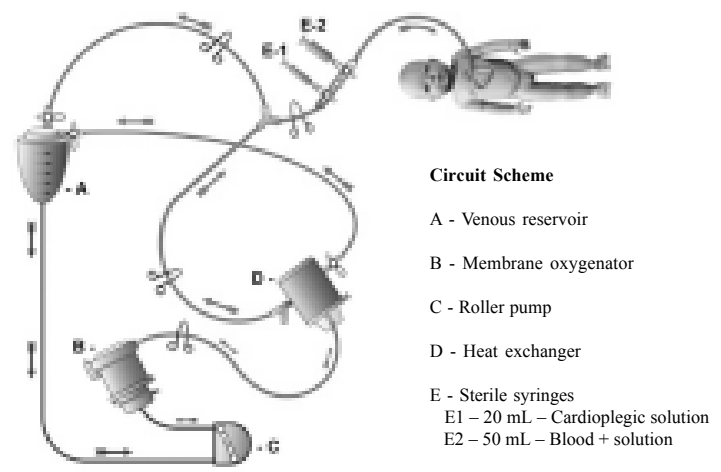

Fig. 1 - Scheme of the cardioplegic system

The blood of the heart-lung machine circuit passed through a mini heat exchanger and returned to the cardiotomy reservoir by a $3 / 16$ line until it acquired a temperature of $8^{\circ} \mathrm{C}$, measured by a thermometer connected to the mini heat exchanger. The line that arrived in the operative field had at its end, two 3-way taps, connected to each other, which were connected to two syringes, one of $20 \mathrm{~mL}$ and the other of $60 \mathrm{~mL}$.

The cardioplegic solution was prepared in a $20-\mathrm{mL}$ syringe which contained $20 \mathrm{mEq} / \mathrm{L}$ of potassium chlorate and $12 \mathrm{mEq} / \mathrm{L}$ of magnesium sulfate. The solution with magnesium was employed in Group I. In Group II, the solution only contained $20 \mathrm{mEq} / \mathrm{L}$ of potassium chlorate. 3 $\mathrm{mL}$ of cardioplegic solution and aspirates of the arterial line, $47 \mathrm{~mL}$ of blood at $8{ }^{\circ} \mathrm{C}$ were placed in the $60 \mathrm{~mL}$ syringe, giving a end cardioplegic solution of $50 \mathrm{~mL}$. This end solution was infused at the aortic root after clamping and drainage of the left chamber by the right superior pulmonary vein or by means of interatrial communication when present.

Surgical correction was then performed and, after completing the atrial sutures, systemic re-heating to an esophageal temperature of $37^{\circ} \mathrm{C}$, removal of the air from the heart chambers and recovery of the heart beats in sinusal rhythm or ventricular fibrillation were achieved. In these latter cases, electric cardioversion with 5 to 10 joules of electric shock was employed. In cases of atrioventricular block, an epimyocardial pacemaker was installed with two leads fixed on the anterior face of the right ventricle.

In patients who required vasoactive drugs, dopamine at 2 to $20 \mathrm{ig} / \mathrm{kg} / \mathrm{min}$ and or dobutamine at a dose of 2.5 to 10 $\mathrm{ig} / \mathrm{kg} / \mathrm{min}$ were used. In patients with systemic arterial hypertension, the chosen drug was endovenous nitroglycerine at a dose of 0.3 to $0.5 \mathrm{ig} / \mathrm{kg} / \mathrm{min}$.

The collection of samples to measure the troponin I and the CK-MB mass levels were according to the following point in the surgery: pre-clamping of the aorta; and 1, 6, 24, 48 , and 72 hours after the end of the aortic clamping. These time intervals were denominated as points $1,2,3,4,5$ and 6 respectively (Figure 2).

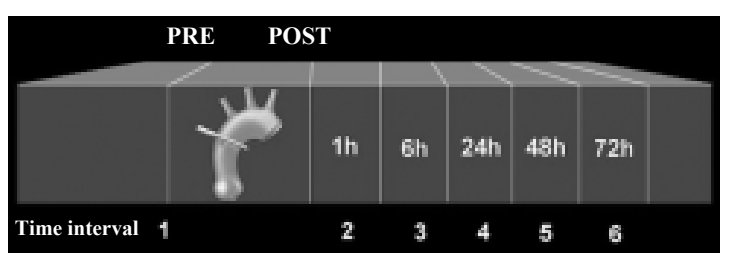

Fig. 2-Scheme of the time intervals of collection of samples.

Analysis of the troponin I and CK-MB mass were made utilizing the chemoluminescence method with the Immulite $\AA$ equipment (DPC-Medlab, USA), using kits of the same brand. The samples remained frozen at $-80{ }^{\circ} \mathrm{C}$ and measurement was made during the same experiment.

The normal reference values of troponin I were considered as $1.0 \mathrm{ng} / \mathrm{mL}$ and for CK-MB mass as $5.8 \mathrm{ng} / \mathrm{mL}$.

For the determination of troponin I and CK-MB mass in relation to operative factors, the peak value was considered, that is, the moment in which these markers reached the highest levels which coincides with the time interval 1 (1 hour after termination of the period of aortic clamping).

The operative factors were subdivided in pre- and intraoperative factors. Among the pre-operative factors the age, gender, weight, presence or not of cyanosis, presence or not of heart failure and the presence or not of pulmonary arterial hypertension were considered. The intra-operative factors were the $\mathrm{CPB}$ time, aortic clamping time and incision in the right ventricle.

The statistical analysis was descriptive of the 28 patients, aiming to verify the homogeneity of the groups in relation to the data which might interfere in the results of the operations. Thus, the quantitative data were summarized by means of the mean and the standard deviation. For this analysis the following tests were utilized: Fisher exact test, the student t-test, Mann-Whitney test, double factor variance analysis with repetitive measurements and multiple regression analysis. 


\section{RESULTS}

There were no statistically significant differences related to the pre-operative characteristics: age ( $\mathrm{p}=0.387$; MannWhitney test), weight ( $\mathrm{p}=0.286$; Mann-Whitney test), gender $(\mathrm{p}=0.434$; Fisher exact test), cyanotic and acyanotic patients $(p=1.00$; Fisher exact test $)$, congestive heart failure $(p=0.718$; Fisher exact test), pulmonary arterial hypertension $(p=1.00$; Fisher exact test), thus confirming the homogeneity of the two groups.

Also there were no statistically significant differences in respect to the following intra-operative characteristics: time of aortic clamping ( $\mathrm{p}=0.860$; student $\mathrm{t}$-test), time of CPB $(\mathrm{p}=0.818$; student $\mathrm{t}$-test $)$, incision of the right ventricle $(p=1.00$; Fisher exact test), mean arterial CPB outflow pressure $(\mathrm{p}=0.395$; student $\mathrm{t}$-test $)$ and urinal outflow during CPB ( $\mathrm{p}=0.634$; student t-test).

Thirteen patients (46.4\%) presented with complications in the post-operative period with: use of vasoactive drugs for greater than six hours (13 patients $-46.4 \%$ ); appearance of CCI (12 patients - $42.9 \%$ ); use of pacemaker (4 patients $14.2 \%)$; increased bleeding ( 3 patients $-10.7 \%)$; intubation for more than 24 hours ( 2 patients $-7.1 \%$ ) and reoperation for review of hemostasis ( 1 patient $-3.6 \%)$.

Hospital mortality was $3.6 \%$ (1 patient). This patient suffered from Fallot's tetralogy of with severe hypoplasia of the pulmonary arterial annulus and of the infundibulum of the right ventricle. The patient presented with significant thrombocytopenia in the post-operative period, disseminated intravascular coagulation and death on the $3^{\text {rd }}$ post-operative day.

In respect to the mean levels of troponin I at the time intervals 1 to 6 (pre-, $1,6,24,48$, and 72 post-clamping hours), there were no statistically significant differences between Groups I and II (Table 1; Figure 3).

In relation to CK-MB mass, there were also no statistically significant differences between the groups at all the time intervals (Table 2; Figure 4).

An univariant analysis of the effect of the operative factors on the peak of troponin I revealed that the following pre- and intra-operative factors showed an association: pulmonary arterial hypertension $(\mathrm{p}=0.015$; student $\mathrm{t}$-test $)$, time of $\mathrm{CPB}$ (coefficient $\mathrm{B}=1.14 ; \mathrm{p}<0.001$; linear regression), time of anoxia (coefficient $\mathrm{B}=1.25 ; \mathrm{p}<0.001 ;$ linear regression), incision of the right ventricle ( $\mathrm{p}=0.015$; student t-test).

However, by means of multiple regression it was confirmed that only cyanosis and time of anoxia revealed significant associations with the peak of troponin I (coefficient B (cyanosis) $=84.72$; coefficient B (time of anoxia) $=0.92 ; \mathrm{p}<0.001$ for both variables $)-$ Figure 5 .
Table 1. Mean values and standard deviation of troponin I (ng/ $\mathrm{mL}$ ) according to the time intervals and the cardioplegia

\begin{tabular}{cccc} 
used. & \multicolumn{3}{c}{ CARDIOPLEGIA } \\
Time Interval & $\begin{array}{c}\text { with Magnesium } \\
(\mathrm{N}=16)\end{array}$ & $\begin{array}{c}\text { without Magnesium } \\
(\mathrm{N}=12)\end{array}$ & $\mathrm{p}^{*}$ \\
\hline & & & \\
1 & $0.33 \pm 0.10$ & $0.39 \pm 0.22$ & 0.377 \\
2 & $76.64 \pm 72.23$ & $56.45 \pm 42.12$ & 0.363 \\
3 & $41.38 \pm 42.53$ & $41.91 \pm 34.78$ & 0.972 \\
4 & $19.75 \pm 17.08$ & $25.67 \pm 20.29$ & 0.410 \\
5 & $12.28 \pm 10.59$ & $17.91 \pm 14.44$ & 0.244 \\
6 & $11.07 \pm 20.60$ & $8.58 \pm 6.33$ & 0.991 \\
\hline
\end{tabular}

$\mathrm{p}$-described level of probability. $*$ Student $\mathrm{t}$-test for independent samples.

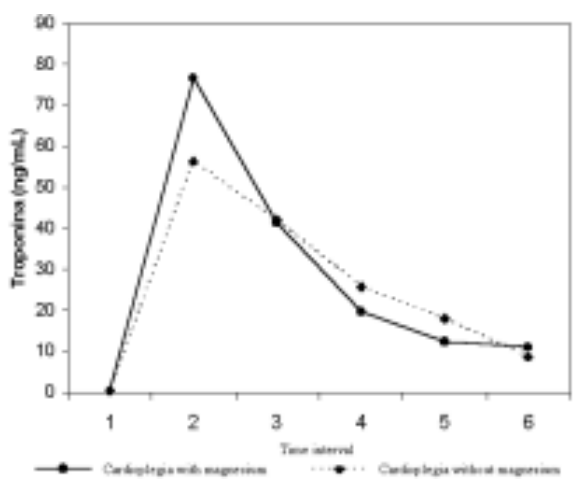

Fig. 3-Mean values of troponin I ( $\mathrm{ng} / \mathrm{mL})$ according to the time intervals and the cardioplegia used

Table 2. Mean values and standard deviation of CK-MB mass $(\mathrm{ng} / \mathrm{mL})$ according to the time intervals and the cardioplegia used.

\begin{tabular}{|c|c|c|c|}
\hline \multirow[b]{2}{*}{ Tizen leserved } & \multicolumn{3}{|c|}{ CARDICFLEOLA } \\
\hline & $\begin{array}{c}\text { nit Magnivien } \\
\text { (1)-10) }\end{array}$ & 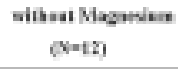 & $r$ \\
\hline 1 & $356 \pm 1.77$ & $297 \pm 156$ & 6374 \\
\hline 2 & $17528 \div 10.32$ & 15585 \& bas 74 & 6.T91 \\
\hline 3 & $13225 \pm 85.76$ & $30360 \pm 02 n$ & oste \\
\hline 4 & $201 \pm 31.2$ & $7125 \pm 47 n$ & 6463 \\
\hline , & $57.49 \pm 28.90$ & $38.14 \pm 2.37$ & 0948 \\
\hline 6 & $10.64 \pm 5.42$ & $956 \pm 932$ & $4 \sin$ \\
\hline
\end{tabular}

$\mathrm{p}-$ described level of probability. $*$ Student t-test for independent samples. 


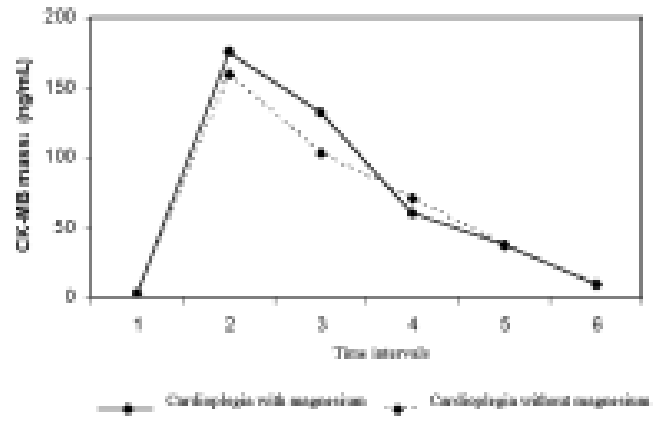

Fig. 4 - Mean values of CK-MB mass (ng/mL) according to the time intervals and the cardioplegia used.

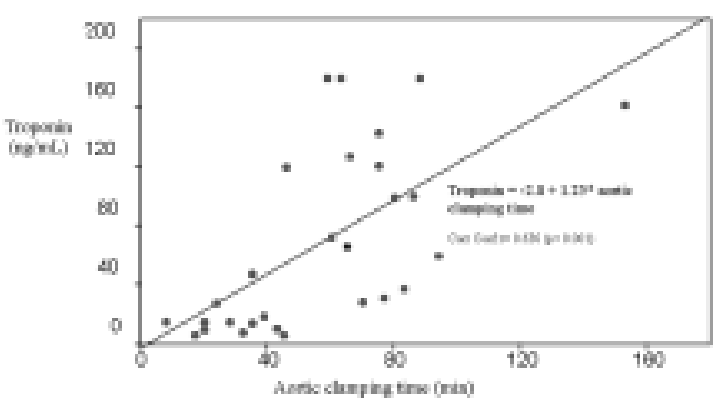

Fig. 5-Correlation between the aortic clamping time and troponin I (time interval 2)

In relation to the CK-MB mass, the univariant analysis revealed that the following pre- and post-operative factors were associated with the peak values of this marker of myocardial lesion: age (coefficient $\mathrm{B}=-1.49 ; \mathrm{p}=0.030$; regression linear), weight (coefficient $B=-6.43 ; p=0.029$ ), cyanosis $(p<0.001$; student $t$-test $)$, pulmonary arterial hypertension ( $\mathrm{p}=0.012$; student t-test), time of perfusion (coefficient $\mathrm{B}=1.62 ; \mathrm{p}=0.036$; regression linear), incision of the right ventricle $(\mathrm{p}=0.011$; student $t$-test $)$.

Multiple regression demonstrated that only cyanosis gave a significant association with the peak of CK-MB mass (coefficient $B=213.63 ; p<0.001$ ).

\section{COMMENTS}

The behavior of the pediatric myocardium in relation to ischemia is different to the adult's myocardium. This fact is due to structural, functional and metabolic differences $[2,7,8]$.

However, clinically the hearts of children are more vulnerable to ischemia, in spite of the use of cardioplegia, when compared to adults $[1,14]$.

In this study we verified whether the addition of magnesium in the cardioplegic solution with the function of blocking the calcium channels, would have an influence on the levels of troponin I and CK-MB mass. Thus, two groups of children who underwent corrective congenital heart disease surgery received, as myocardial protection, cold sanguineous cardioplegia with or without magnesium.

The results of this study revealed that the levels of troponin I and CK-MB mass increased in both groups, without presenting with statistically significant differences. The behavior of these markers was to peak in the first hour after aortic clamping, diminishing over the subsequent 71 hours to near-normal levels. This increase suggests that despite of the cardioplegia employed, with or without magnesium, there was myocardial lesion. From this it can be inferred that the addition of magnesium in the cardioplegic solution does not give adequate protection to the myocardium.

The fact that lower levels of troponin I and CK-MB mass were not found in the group that received magnesium raises some questions. Initially, if the type of marker employed to detect the presence of myocardial lesion is considered reliable to detect myocardial damage. Troponin I and CKMB mass are chosen due to their specifications and sensitivities. Troponin I is a cardio-specific protein, whilst CK-MB mass is considered to be a protein fraction measured by immunoassay [15-17]. However, it can be inferred that the markers utilized were not responsible for not detecting the differences between the two groups.

In respect to the vehicle of the cardioplegia, the composition of the solution might influence the preservation of the cardiac fiber $[18,19]$.

The concentration of calcium in the cardioplegia has an important role. Accumulation of its ion in the intercellular space after a period of ischemia is associated with cellular lesions [20].

The utilization of a cardioplegic solution with magnesium could serve to block the deleterious effect of calcium. However, when normocalcemic or even hypocalcaemic solution is used, this benefit might not appear, specifically in hearts of children suffering from acyanogenic heart disease [20].

The cardioplegia used in the present study was normocalcemic, as the blood of the patient was used to fill the $\mathrm{CPB}$ circuit. This fact might explain why the levels of troponin I and CK-MB mass were not statistically different between the children who received cardioplegia with and without magnesium. However, this result should be considered with a certain caution. Despite of the homogeneity between the groups, the small number of patients could have prejudiced the detection of differences that by chance could exist between those who received magnesium and those who did not. 
In respect to the influence of cyanosis on the levels of troponin I and CK-MB mass in relation to the type of cardioplegia utilized, probably, this could have been observed if the number of cyanotic patients was greater than the number of acyanotic patients. When we analyzed the levels of troponin I and CK-MB mass in these cyanotic patients, we found higher levels when compared with the acyanotic patients. However, in a sample with only acyanotic patients in a group and cyanotic in another, we could possibly find statistically significant differences with the use of magnesium in the cardioplegic solution.

The type of cardioplegia used is not the only factor that participates in myocardial lesions. The presence of cyanosis and ventricular dilatation provoked by the lesions that develop due to the shunt, can negatively influence the functioning of the cardiac muscle [20].

In this aspect we tried to verify which pre- and intraoperative factors might independently interfere in the increase of the levels of troponin I and CK-MB mass.

A positive association was evidenced between the peak of troponin I and the presence of cyanosis. This result seems to have relevance by the fact that cyanosis is an independen factor which influences the peak of troponin I and CK-MB mass, without being influenced by the pre-operative factors: gender, weight, age, presence of congestive heart failure and pulmonary arterial hypertension. This finding is confirmed by published results. Children with cyanogenic congenital heart diseases submitted to corrective surgery evolve with higher levels of troponin I and this negatively influences the post-operative evolution [21].

These findings reinforce the idea that the myocardium of the child with cyanogenic heart disease develops with metabolic and functional alterations. From the metabolic point of view, the levels of ATP and reserve of glycogen in the myocardial fiber are lower. Additionally, the functional behavior is prejudiced, reflecting in a greater necessity of vasoactive drugs and low post-operative output [22].

Thus in the same way as the pre-operative factors, we tried to evaluate if any intraoperative factors, such as the time of $\mathrm{CPB}$, time of aortic clamping and incision of the right ventricle, would have an independent effect on the increase in the levels of troponin I and CK-MB mass.

In this study we found a positive correlation between the marker of myocardial lesions and the time of aortic clamping. The other intraoperative factors did not exert any effect on the peak levels of troponin I or CK-MB mass. This correlation might be useful as for prognosis in the postoperative period. Patients with lower levels of troponin I can present with a lesser need of vasoactive drugs and less myocardial failure. These data are in agreement with the results of the work by BULL et al. [1].
IMURA et al. [21] also found a correlation between the time of aortic clamping and levels of troponin I. This association is even more evident in under 1 -year-old children.

KIRKLIN et al. [14] emphasized the importance of the influence of congestive heart disease in the pre-operative period, interfering in the evolution after corrective surgery. It is possible to see in this study, using univariant analysis, that congestive heart failure in the pre-operative period had an influence on the peak of troponin I and CK-MB mass. However, with multiple regression analysis this behavior was not verified. This leads us to believe that congestive heart failure in isolation has an effect on the peak of the markers, but on associating with other pre-operative factors this influence is reduced and cyanosis appears as the preponderant factor to affect the peaks of troponin I and CK-MB mass. Nevertheless, when we analyze the patients who presented with complications in the postoperative period, we confirmed that congestive heart failure was present in the patients who developed with higher levels of troponin I and CK-MB mass. This finding may be explained by the volumetric or pressure overload that the myocardium of children with congenital heart diseases is submitted since the intra-uterine life. This may lead to depletion of the ATP and high-energy phosphates that intensify after a period of ischemia provoked by aortic clamping [23].

The myocardium of a child should be considered by the surgeon as an extremely important structure. The presence of cyanosis is a factor that would have a negative influence on the myocardial function, however, it should receive adequate protection. Apart from cyanosis, the time of aortic clamping should also be considered as a potential cause of myocardial damage, in spite of the cardioplegia employed to protect it.

Future studies with a greater number of patients, different concentrations of calcium in the cardioplegia and divided in groups with similar congenital heart diseases might reveal the protective effect of magnesium, reflected by the lower levels of troponin I and CK-MB mass.

\section{CONCLUSIONS}

Faced with these results, we believe that the addition of magnesium to cardioplegic solutions does not interfere with the levels of troponin I and CK-MB mass in children operated on for corrective congenital heart surgery. On the other hand, the factors cyanosis and time of anoxia affected the peak of troponin I and the factor cyanosis affected the peak of CKMB mass. 


\section{BIBLIOGRAPHIC REFERENCES}

1. Bull C, Cooper J, Stark J. Cardioplegic protection of the child's heart. J Thorac Cardiovasc Surg 1984; 88: 287-93.

2. Friedman WF. The intrinsic physiologic properties of the developing heart. Prog Cardiovasc Dis 1972; 15: 87-111.

3. Hopkins SF Jr., McCutcheon EP, Wekstein DR. Postnatal changes in rat ventricular function. Circ Res 1973; 32: 685-91.

4. Boland R, Martonosi A, Tillack TW. Developmental changes in the composition and function of sarcoplasmatic reticulum. J Biol Chem 1974; 249:612-23.

5. Lodge NJ, HuddartiH. Calcium exchange in the adult and neonatal canine myocardium (abstract). Pediatric Cardiol 1984; 5:253.

6. Pridjian AK, Levitsky S, Krukenkamp I, Silverman NA, Feinberg H. Developmental changes in reperfusion injury: a comparison of intracellular cation accumulation in the newborn, neonatal, and adult heart. J Thorac Cardiovasc Surg 1987; 93:428-33.

7. Romero T, Covell J, Friedman WF. A comparison of pressurevolume relations of the fetal, newborn, and adult heart. Am J Physiol 1972; 222: 1285-90.

8. Baldwin KM, Cooke DA, Cheadle WG. Enzyme alterations in neonatal heart muscle during development. J Mol Cell Cardiol 1977; 9: 651-60

9. Corno AF, Bethencourt DM, Laks H, Haas GS, Bhuta S, Davtyan HG et al. Myocardial protection in the neonatal heart: a comparison of topical hypothermia and crystalloid and blood cardioplegic solutions. J Thorac Cardiocasc Surg 1987; 93: 163-72.

10. Jennings RB, Somers HM, Kaltenbach JP, West JJ. Electrolyte alterations in acute myocardial ischemic injury. Cir Res 1964; 14: $260-3$.

11. Shen AC, Jennings RB. Myocardial calcium and magnesium in acute ischemic injury. Am J Pathol 1972; 67: 417-40.

12. Mair J. Cardiac troponin I and troponin T: are enzymes still relevant as cardiac markers? Clin Chim Acta 1997; 257:99-115.

13. Godoy MF, Braile DM, Purini Neto J. A troponina como marcador de injuria celular miocárdica. Arq Bras Cardiol 1998; 71: 629-33.
14. Kirklin JK, Blackstone EH, Kirklin JW, McKay R, Pacifico $\mathrm{AD}$, Bargeron Jr. LM. Intracardiac surgery in infants under age 3 months: incremental risk factors for hospital mortality. Am J Cardiol 1981; 48: 500-6.

15. Hirsch R, Landt Y, Porter S, Canter CE, Jaffe AS, Ladenson JH et al. Cardiac troponin I in pediatrics: normal values and potential use in the assessment of cardiac injury. J Pediatric 1997; 130: 872-7.

16. Hirsch R, Dent CL, Wood MK, Huddleston CB, Mendeloff EM, Balzer DT et al. Patterns and potential value of cardiac troponin I elevations after cardiac operations. Ann Thorac Surg 1998; 65: 1394-9.

17. Henderson AR. An overview and ranking of biochemical markers of cardiac disease: strengths and limitations. Clin Lab Med 1997; 17: 625-54.

18. Engelman RM, Rousou JH, Dobbs W, Pels MA, Longo F. The superiority of blood cardioplegia in myocardial preservation. Circulation 1980; 62 (2 Pt 2): I62-6.

19. Hearse DJ, Stewart DA, Braimbridge MV. Myocardial protection during ischemic cardiac arrest: the importance of magnesium in cardioplegic infusates. J Thorac Cardiovasc Surg 1978; $75: 877-85$.

20. Kronon M, Bolling KS, Allen BS, Rahman S, Wang T, Halldorsson A et al. The relationship between calcium and magnesium in pediatric myocardial protection. J Thorac Cardiovasc Surg 1997; 114: 1010-9.

21. Imura H, Caputo M, Parry A, Pawade A, Angelini GD, Suleiman MS. Age-dependent and hypoxia-related differences in myocardial protection during pediatric open heart surgery. Circulation 2001; 103: 1551-6.

22. Najm HK, Wallen WJ, Belanger MP, Williams WG, Coles JG, Van Arsdell GS et al. Does the degree of cyanosis affect myocardial adenosine triphosphate levels and function in children undergoing surgical procedures for congenital heart disease? J Thorac Cardiovasc Surg 2000, 119: 515-24.

23.Taggart DP, Hadjinikolas L, Wong K, Yap J, Hooper J, Kemp $\mathrm{M}$ et al. Vulnerability of paediatric myocardium to cardiac surgery. Heart 1996; 76: 214-7. 